\title{
Membrane Lipid Rafts Are Necessary for the Maintenance of the $\alpha 7$ Nicotinic Acetylcholine Receptor in Somatic Spines of Ciliary Neurons
}

\author{
Juan L. Brusés, Norbert Chauvet, and Urs Rutishauser \\ Cellular Biochemistry and Biophysics Program, Memorial Sloan-Kettering Cancer Center, New York, New York 10021
}

Calcium-permeable neurotransmitter receptors are concentrated into structurally and biochemically isolated cellular compartments to localize calcium-mediated events during neurotransmission. The cytoplasmic membrane contains lipid microdomains called lipid rafts, which can gather into microscopically visible clusters, and thus the association of a particular protein with lipid rafts can result in its redistribution on the cell surface. The present study asks whether lipid rafts participate in the formation and maintenance of the calciumpermeable $\alpha 7$-subunit nicotinic acetylcholine receptor $(\alpha 7 \mathrm{nAChR})$ clusters found in somatic spines of ciliary neurons. Lipid rafts and $\alpha 7 \mathrm{nAChR}$ become progressively colocalized within somatic spines during synaptogenesis. To determine whether these rafts are required for the maintenance of $\alpha 7 n A C h R$ aggregates, cholesterol was extracted from dissociated ciliary neurons by treatment with methyl- $\beta$-cyclodextrin. This treatment caused the dispersion of lipid rafts and the redistribution of $\alpha 7 \mathrm{nAChR}$ into small clusters over the cell surface, suggesting that the integrity of lipid rafts is required to maintain the receptor clustering. However, lipid raft dispersion

Neurotransmitter receptors are highly concentrated in the area of functional contact between excitable cells. The localization and clustering of the relevant receptor on the cell surface at and within the appropriate contact site are critical for the triggering and integration of neurotransmission.

The plasma membrane is mainly composed of a fluid bilayer of phospholipids within which integral and peripheral membrane proteins diffuse. Therefore diffusion forces must be neutralized to maintain a high receptor density in the area of synaptic contact. To this end, there are two basic mechanisms by which lateral dispersion of receptors can be influenced: the assembly of molecular scaffolds via protein-protein interactions that link the receptor to the cytoskeleton and the existence of specific domains of the membrane to which receptors are either inserted or recruited.

Several proteins have been identified that interact with neurotransmitter receptors, including rapsyn (Froehner, 1991; Phillips et al., 1991; Gautam et al., 1995; Ramarao and Cohen, 1998),

Received July 27, 2000; revised Oct. 25, 2000; accepted Oct. 30, 2000.

This study was supported by National Institutes of Health Grants EY06107 and HD18369. N.C. was supported in part by the Institut National de la Santé et de la Recherche Médicale. We thank Drs. William G. Conroy and Darwin K. Berg of the University of California at San Diego for providing the monoclonal antibody 319 against the $\alpha 7$ subunit of the nicotinic acetylcholine receptor.

Correspondence should be addressed to Dr. Juan L. Brusés, Memorial SloanKettering Cancer Center, 1275 York Avenue, Box 290, New York, NY 10021. E-mail: j-bruses@ski.mskcc.org.

Copyright (C) 2001 Society for Neuroscience 0270-6474/01/210504-09\$15.00/0 also caused the depolymerization of the F-actin cytoskeleton, which can also tether the receptor at specific sites. To assess whether interaction between rafts and $\alpha 7 \mathrm{nAChR}$ is independent of F-actin filaments, the lipid raft patches were stabilized with a combination of the cholera toxin B subunit (CTX), which specifically binds to the raft component ganglioside GM1, and an antibody against CTX. The stabilized rafts were then treated with latrunculin-A to depolymerize F-actin. Under these conditions, large patches of CTX persisted and were colocalized with $\alpha 7 \mathrm{nAChR}$, indicating that the aggregates of receptors can be maintained independently of the underlying F-actin cytoskeleton. Moreover, it was found that the $\alpha 7 \mathrm{nAChR}$ is resistant to detergent extraction at $4^{\circ} \mathrm{C}$ and floats with the caveolincontaining lipid-rich fraction during density gradient centrifugation, properties that are consistent with a direct association between the receptor and the membrane microdomains.

Key words: ciliary ganglion; somatic spines; lipid rafts; $\alpha 7$ nicotinic acetylcholine receptor; receptor clusters; actin cytoskeleton; synapse formation gephyrin (Prior et al., 1992; Meyer et al., 1995), GABA-Rassociated protein (Wang et al., 1999), postsynaptic density 95 (PSD95) (Kornau et al., 1995), and PKC $\alpha$-interacting protein 1 (PICK1) (Xia et al., 1999). Rapsyn and gephyrin have been shown to be required for clustering of the muscular nicotinic acetylcholine receptor (nAChR) and neuronal glycine receptors, respectively (Gautam et al., 1995; Feng et al., 1998b), whereas PSD95 and PICK1 use PDZ domains to couple the glutamatergic NMDA and AMPA receptor to other cell components or functions (Kornau et al., 1997; Craven and Bredt, 1998). Additional mechanisms must also exist because, for example, the $\mathrm{C}$ terminal of a subfamily of ligand-activated ion channel subunits (ACh, GABA, serotonin, and glycine receptors) cannot bind to PDZ proteins (Barnard, 1992), and although the clustering of nAChR in muscle (Gautam et al., 1995) requires rapsyn, its close homolog in autonomic neurons does not (Burns et al., 1997; Feng et al., 1998a; Conroy and Berg, 1999).

In addition to the fluid bilayer, the cytoplasmic membrane contains small lipid membrane microdomains called lipid rafts, which are enriched in sphingolipids and cholesterol and are resistant to nonionic detergent extraction at $4^{\circ} \mathrm{C}$ (Simons and Ikonen, 1997; Brown and London, 1998). Membrane proteins partition differentially into these lipid microdomains. For example, glycosylphos-phatidylinositol-linked proteins, some transmembrane proteins, and tyrosine kinases of the $s r c$ family are enriched in lipid rafts (Simons and Ikonen, 1997; Jacobson and 
Dietrich, 1999). Because lipid rafts can move laterally and cluster into larger patches (Harder et al., 1998), the association of a particular protein with rafts can result in its redistribution, and therefore they have been proposed to function as membrane platforms for the assembly of signaling complexes and for the sorting of surface molecules to particular cellular structures (Simons and Ikonen, 1997; Stauffer and Meyer, 1997; Viola et al., 1999).

On this basis it is reasonable to ask whether lipid rafts might be a factor in the redistribution of some neurotransmitter receptors, as well as other synaptic components. The present study was designed to determine whether cholesterol-rich lipid microdomains influence the clustering of acetylcholine receptor within somatic spines in neurons. To this end, the ciliary neurons of the chick ciliary ganglion (CG) have been used as an experimental model. These cholinergic neurons express high levels of the homomeric $\alpha$ bungarotoxin ( $\alpha \mathrm{BTX})$-sensitive $\alpha 7 \mathrm{nAChR}$ that is highly concentrated in somatic spine aggregates localized over discrete areas of the ciliary neuron soma (Shoop et al., 1999). $\alpha 7 \mathrm{nAChRs}$ are permeable to calcium, and their clustering in somatic spines is required for its proper function (Liu and Berg, 1999).

\section{MATERIALS AND METHODS}

Animals. Fertilized White Leghorn chicken eggs from SPAFAS (Roano$\mathrm{ke}, \mathrm{IL})$ were incubated in a forced-draft incubator at $39^{\circ} \mathrm{C}$ under a humidified atmosphere until the desired embryonic stage $(\mathrm{St})$ was reached (Hamburger and Hamilton, 1951).

Labeling of intact $C G$. CGs from varying embryonic stages were dissected and treated with collagenase A (Boehringer Mannheim, Indianapolis, IN; $2 \mathrm{mg} / \mathrm{ml}$ in PBS for $20 \mathrm{~min}$ at $37^{\circ} \mathrm{C}$ in a water bath) to facilitate penetration of markers. Ganglia were then incubated in tetramethylrhodamine-conjugated $\alpha$ BTX (RITC- $\alpha$ BTX; $2 \mu \mathrm{g} / \mathrm{ml}$; Molecular Probes, Eugene, OR) and biotin-conjugated cholera toxin B subunit (biotin-CTX; $20 \mu \mathrm{g} / \mathrm{ml}$; Sigma, St. Louis, MO) for $2 \mathrm{hr}$ at $16^{\circ} \mathrm{C}$. Thereafter, the ganglia were washed, fixed in $4 \%$ paraformaldehyde in phosphate buffer $(0.1 \mathrm{M}), \mathrm{pH} 7.4$, for $30 \mathrm{~min}$ at room temperature (RT), incubated in Cy2-conjugated streptavidin $(2 \mu \mathrm{g} / \mathrm{ml}$; Jackson ImmunoResearch, West Grove, PA) for $2 \mathrm{hr}$ at RT, mounted in Mowiol, and observed by confocal microscopy with an LSM510 Zeiss Axiovert microscope.

Labeling of cultured ciliary neurons. St 40 CGs were dissected and collected in $\mathrm{Ca}^{2+}-\mathrm{Mg}^{2+}$-free Tyrode's solution on ice. The ganglia were then incubated in collagenase A $(2 \mathrm{mg} / \mathrm{ml}$ in PBS $)$ for $45 \mathrm{~min}$ at $37^{\circ} \mathrm{C}$, mechanically dissociated with fire-polished Pasteur pipettes, and plated on plastic tissue culture dishes precoated with poly-D,L-ornithine or poly-D,L-lysine $(0.2 \mathrm{mg} / \mathrm{ml})$ and laminin $\left(1 \mu \mathrm{g} / \mathrm{cm}^{2}\right)$. Cells were then cultured in DMEM and F12 plus insulin $(5 \mu \mathrm{g} / \mathrm{ml})$ for $1 \mathrm{hr}$ in a tissue culture incubator at $37^{\circ} \mathrm{C}$. Labeling of $\alpha 7 \mathrm{nAChR}$ was performed by incubating the cultured cells with RITC- $\alpha$ BTX $(2 \mu \mathrm{g} / \mathrm{ml})$ in Dulbecco's PBS (D-PBS; Life Technologies, Gaithersburg, MD), pH 7.4, for $1 \mathrm{hr}$ on ice. In some cases, Alexa488-conjugated $\alpha$ BTX (Alexa488- $\alpha$ BTX; Jackson ImmunoResearch) was used at a concentration of $10 \mu \mathrm{g} / \mathrm{ml}$ to label $\alpha 7 \mathrm{nAChR}$.

CTX was used as a marker for cholesterol-rich lipid microdomains. CTX binds to the ganglioside GM1 (Schon and Freire, 1989), which is an abundant lipid raft component and thus has been extensively used as a lipid raft marker in a variety of cells (Harder et al., 1998; Viola et al., 1999) including neurons (Ledesma et al., 1998). The ability of CTX to label cholesterol-rich lipid microdomains in ciliary neurons was tested by removing cholesterol from the cultured cells. As has been observed in other cell types (Janes et al., 1999), cholesterol removal causes the dispersion of lipid raft patches in ciliary neurons (see Fig. 4). Cultured ciliary neurons were incubated with fluorescein-conjugated CTX (FITCCTX; Sigma) at a concentration of $10 \mu \mathrm{g} / \mathrm{ml}$ in D-PBS for $1 \mathrm{hr}$ on ice. Cells were then washed with D-PBS and fixed in $4 \%$ paraformaldehyde in $0.1 \mathrm{M}$ phosphate buffer, $\mathrm{pH} 7.4$, for $30 \mathrm{~min}$ at RT. The neural cell adhesion molecule (NCAM) was immunodetected with a monoclonal antibody (5e) that recognizes all NCAM isoforms (Watanabe et al., 1986) followed by Cy2-conjugated goat anti-mouse IgG antibodies (Jackson ImmunoResearch) at $7.5 \mu \mathrm{g} / \mathrm{ml}$ for $1 \mathrm{hr}$. Polymerized actin filaments
(F-actin) were detected with tetramethylrhodamine-conjugated phalloidin (RITC-phalloidin; Molecular Probes), a fungus venom that specifically binds to F-actin (Vandekerckhove et al., 1985). Cultured cells were fixed as described above, permeabilized in D-PBS with $0.05 \%$ Triton $\mathrm{X}-100$ for $20 \mathrm{~min}$, and then incubated for $1 \mathrm{hr}$ in D-PBS containing RITC-phalloidin.

Electron microscopy. Dissociated ciliary neurons were plated on Aclar and cultured for $1 \mathrm{hr}$ in a tissue culture incubator at $37^{\circ} \mathrm{C}$. Cells were then incubated with peroxidase-conjugated CTX (10 $\mu \mathrm{g} / \mathrm{ml}$; Sigma) for $1 \mathrm{hr}$ on ice, washed, and incubated in a 1:50 dilution of anti-peroxidase antibody conjugated to $6 \mathrm{~nm}$ immunogold particles (Jackson ImmunoResearch) in D-PBS with $2 \%$ BSA for $1 \mathrm{hr}$ on ice. Cells were then fixed with $4 \%$ paraformaldehyde and $2.5 \%$ glutaraldehyde for $1 \mathrm{hr}$, washed, postfixed in $1 \%$ osmium tetroxide, dehydrated, and infiltrated by Epon resin. Ultrathin sections were cut and observed using a JEOL electron microscope. The number of immunogold particles per unit membrane length was estimated from electron microphotographs of ciliary neurons following the procedure of Shoop et al. (1999). Briefly, neuronal membrane was divided into two classes: "spiny" and "nonspiny" membrane. A spine was defined as a protrusion from the cell body of at least $0.2 \mu \mathrm{m}$. A nonspiny or smooth cell surface was defined as a flat cell membrane with no depressions or bumps that could indicate the origin of a spine. The total number of gold particles along each type of membrane was summed and divided by the total length of membrane observed from $\sim 20$ cells. Membrane length was measured using NIH Image software.

Quantification of fluorescence intensities and the fluorescence intensity ratio. NIH Image software was used to determine the average fluorescence intensity of various markers independently over distinct areas of the cell surface from mid-cell section confocal images $(1 \mu \mathrm{m}$ thick). Midcell sections were selected because they help to determine whether a marker is localized at the cell surface. To analyze the differential distribution of molecules over discrete regions of the cell surface, ciliary neurons were double-stained with RITC- $\alpha$ BTX or Alexa488- $\alpha$ BTX and with one of the following markers: FITC-CTX, RITC-phalloidin, or Cy2-conjugated anti-mouse IgG to label anti-NCAM antibody. Fluorescently labeled $\alpha \mathrm{BTX}$ was used to identify $\alpha 7 \mathrm{nAChR}$ clusters in somatic spines. The average fluorescence intensity of a predetermined area $(18 \times$ 18 pixel square corresponding to $2.94 \mu \mathrm{m}^{2}$ ) was measured within the $\alpha$ BTX-positive region of the cell and divided by the average fluorescence intensity of an area of the same size positioned over an $\alpha$ BTX-negative region of the membrane, which corresponded to the smooth surface of the cell. The ratio between these two fluorescence intensity values was calculated for $\sim 20$ cells from each experimental condition, with a ratio of 1 indicating a homogeneous distribution of the marker. A similar procedure for quantifying the synaptic clustering of molecules has been reported (Craven et al., 1999).

Line profiles. To determine the line profiles of the membrane fluorescence intensity for a given marker, a line was drawn over the cell circumference from a confocal section, and the fluorescence intensity was determined independently for each marker over the same area and plotted as relative intensity versus relative distance.

Assessment of the number and size of molecular clusters. To estimate the magnitude of the effect of drug treatments on the $\alpha 7 \mathrm{nAChR}$ clustering, two parameters were selected: the average number of clusters of a particular molecular marker per cell section and the average size of the clusters (total cluster area divided by the number of clusters in the cell section). An arbitrary fix threshold for the average fluorescent intensity of a minimum cell area was set to detect molecular clusters automatically. A cluster was defined as an area of 20 or more adjacent pixels $\left(0.18 \mu \mathrm{m}^{2}\right)$ with an average fluorescence intensity above threshold.

Triton X-100 flotation gradients. To analyze detergent-insoluble components of the cell membrane, the method of Bruckner et al. (1999) was followed with small modifications. Briefly, 50-60 St 40-42 CGs were collected on ice and homogenized by 20 strokes in a Dounce with $300 \mu \mathrm{l}$ of ice-cold homogenization buffer $(20 \mathrm{~mm}$ Tris- $\mathrm{HCl}, \mathrm{pH} 7.4,50 \mathrm{~mm}$ $\mathrm{NaCl}, 250 \mathrm{~mm}$ sucrose, and $1 \mathrm{~mm}$ DTT) and protease inhibitor cocktail (Complete, Mini, EDTA-free; Boehringer-Mannheim; one tablet in 10 $\mathrm{ml})$. The extract was then passed five times through a 22 gauge needle and centrifuged at $735 \times g(3000 \mathrm{RPM})$ for $10 \mathrm{~min}$ in an Eppendorf microcentrifuge at $4^{\circ} \mathrm{C}$. The supernatant was saved, and the pellet was reextracted with $100 \mu \mathrm{l}$ of homogenization buffer by passing five times through a 22 gauge needle and spun as described above. Both supernatants were combined in an ultracentrifuge tube, brought to $35 \%$ Optiprep (Nycomed Pharma, Oslo, Norway) by adding $550 \mu \mathrm{l}$ of $60 \%$ Optiprep, and overlayered successively with $1 \mathrm{ml}$ of 30,20, and 5\% Optiprep 


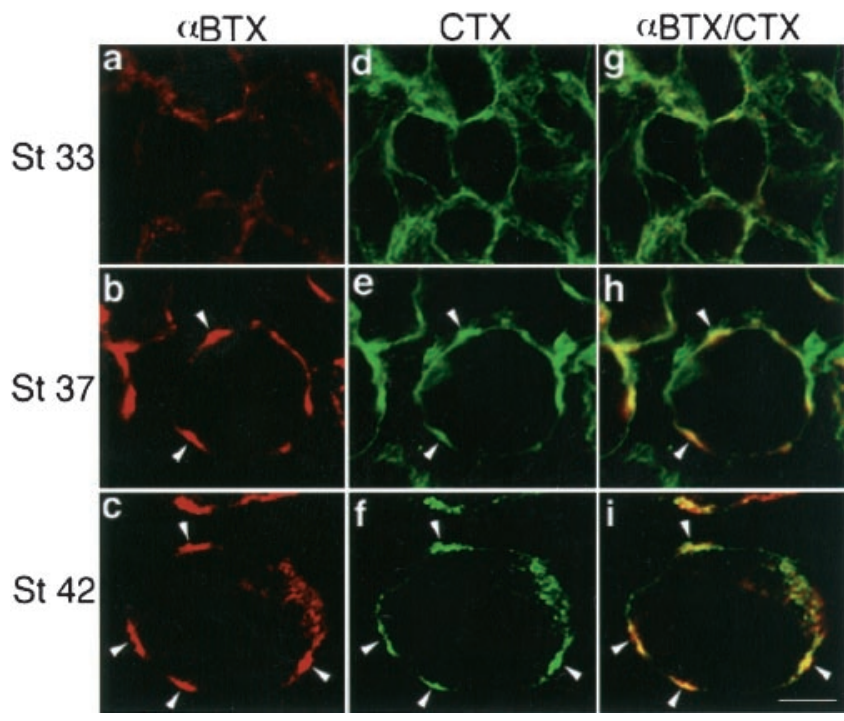

Figure 1. Colocalization of $\alpha 7 \mathrm{nAChR}$ and membrane lipid rafts during ciliary neuron development. Intact CGs from St 33, 37, and 42 chick embryos were double-labeled with RITC- $\alpha$ BTX (red) and FITC-CTX (green) to analyze the developmental distribution of $\alpha 7 \mathrm{nAChR}$ and membrane lipid rafts, respectively. The samples were observed by confocal microscopy, and the same cell sections are presented for both markers $a$, At St 33, $\alpha \mathrm{BTX}$ is expressed over the surface of the ciliary neurons in poorly defined patches. $d, g, \mathrm{CTX}(d)$ is detected over the entire cell body and only partially colocalizes with $\alpha \mathrm{BTX}$ ( $g$; yellow). $b$, By St $37, \alpha \mathrm{BTX}$ labeling is more intense and concentrated in defined patches (arrowheads).e, $h, \mathrm{CTX}(e)$ also labels the $\alpha \mathrm{BTX}$-positive areas indicated by the arrowheads (yellow, arrowheads in $h$ represent the areas where both markers overlap); however CTX is also localized to areas not labeled by $\alpha \mathrm{BTX}$ ( $h$; green). $c$, $f$, At St 42 , when ciliary neurons have matured and formed distinct mats of somatic spines along the cell surface, both $\alpha$ BTX and CTX, respectively, are only detected on well defined patches (arrowheads). $i$, At this stage both markers are almost completely colocalized as indicated by the overlay (arrowheads). Scale bar, $10 \mu \mathrm{m}$.

in homogenization buffer. The sample was centrif uged in a SW55Ti rotor at $285,000 \times g(49,000 \mathrm{RPM})$ for $3 \mathrm{hr}$ at $4^{\circ} \mathrm{C}$, and 12 fractions were collected. The third and fourth fractions from the top, containing the membrane, were combined and adjusted to $0.1 \%$ Triton X-100 (Calbiochem, La Jolla, CA; protein grade) and incubated on wet ice for $30 \mathrm{~min}$. Thereafter, the sample was adjusted to $35 \%$ Optiprep, overlayered with $2.5 \mathrm{ml}$ of $30 \%$ Optiprep plus $0.1 \%$ Triton X-100 and $0.5 \mathrm{ml}$ of homogenization buffer plus $0.1 \%$ Triton $\mathrm{X}-100$, and spun as described above for $4 \mathrm{hr}$. After centrifugation, six equal fractions were collected. A $60 \mu \mathrm{l}$ aliquot from each sample was put aside, and $500 \mu$ l of solubilization solution was added to the remaining sample and incubated with $75 \mu \mathrm{l}$ of $\alpha \mathrm{BTX}$ conjugated-Actigel overnight at $4^{\circ} \mathrm{C}$ with rotation. The samples were then washed three times with solubilization solution, twice with of $0.1 \mathrm{~m}$ phosphate buffer, $\mathrm{pH} 7.3,0.5 \%$ Triton $\mathrm{X}-100$, and $1 \mathrm{M} \mathrm{NaCl}$, and twice with $0.1 \mathrm{M}$ phosphate buffer, $\mathrm{pH} 7.3$, and $0.5 \%$ Triton $\mathrm{X}-100$ and resuspended in $50 \mu \mathrm{l}$ of Laemmli sample buffer. Both sets of samples were analyzed by $10 \%$ SDS-PAGE and Western blotting with the rat monoclonal antibody 319 against $\alpha 7 \mathrm{nAChR}$ (kindly provided by Drs. W. Conroy and D. Berg of the University of California at San Diego) and a rabbit polyclonal against caveolin (Transduction Laboratories, Lexington, $\mathrm{KY}$; \#13630).

Drugs and treatments. Methyl- $\beta$-cyclodextrin (MBC; Sigma) was used to extract cholesterol from the cell membrane. MBC contains a hydrophobic cavity that specifically binds cholesterol, rendering it soluble in aqueous solutions, and thus reduces the cholesterol content of the cell (Klein et al., 1996). Cultured cells were incubated for $1 \mathrm{hr}$ at $37^{\circ} \mathrm{C}$ in a tissue culture incubator in culture medium containing $8 \mathrm{~mm} \mathrm{MBC}$. This procedure was found to extract $\sim 70 \%$ of cellular cholesterol (Harder et al., 1998; Keller and Simons, 1998). To destabilize the F-actin cortical cytoskeleton of cultured ciliary neurons, cells were incubated for $2 \mathrm{hr}$ at $37^{\circ} \mathrm{C}$ with latrunculin-A (LAT-A; Molecular Probes) at a concentration of $20 \mu \mathrm{g} / \mathrm{ml}$. LAT-A is a membrane-permeant toxin isolated from the Red Sea sponge Negombata (Spector et al., 1983) that specifically binds
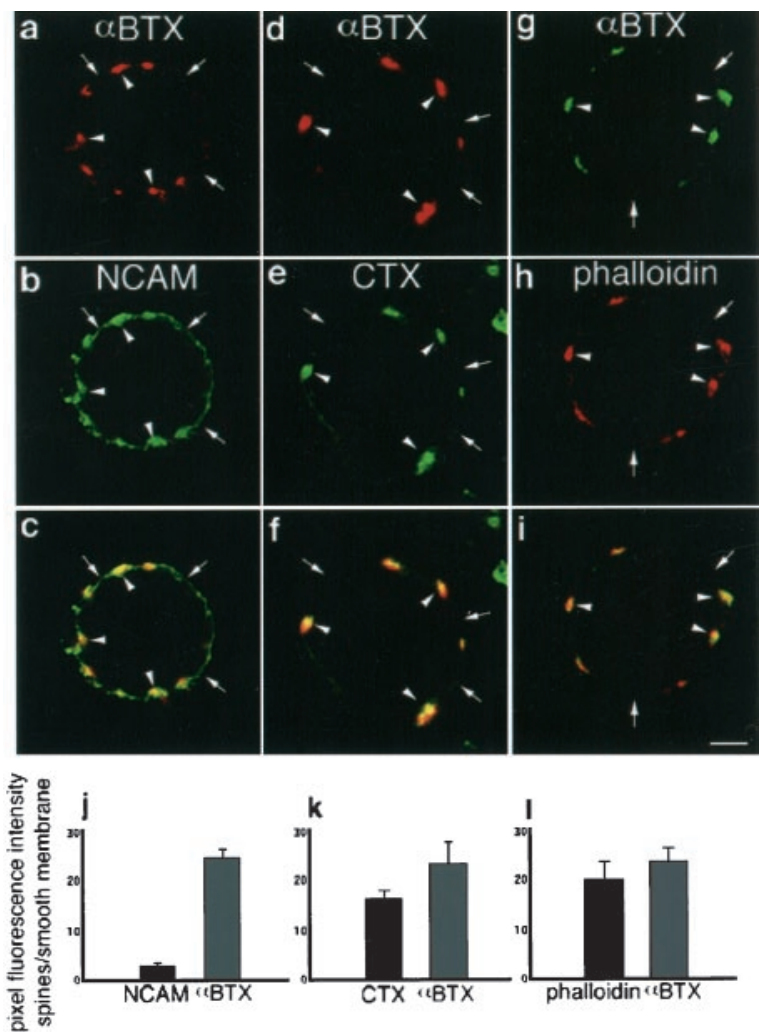

Figure 2. Membrane lipid rafts are associated with $\alpha$ BTX-positive clusters and F-actin aggregates. Freshly dissociated St 40 ciliary neurons were double-labeled with RITC- $\alpha$ BTX and anti-NCAM antibodies followed by Cy2-conjugated secondary antibodies $(a-c)$, with RITC- $\alpha$ BTX and FITC-CTX $(d-f)$, or with Alexa488- $\alpha$ BTX and RITC-phalloidin $(g-i)$. Confocal midsections of the cells were collected for analyses. $a, \alpha \mathrm{BTX}-$ positive regions of the cell surface are indicated by arrowheads, whereas arrows point to areas negative for $\alpha \mathrm{BTX}$. $b$, Same cell shown in $a$ is labeled with NCAM and indicates NCAM-positive regions that are both NCAM positive (arrowheads) and $\alpha \mathrm{BTX}$ negative (arrows). $c$, Overlay of $a$ and $b$ is shown. $d$, Arrowheads and arrows point to $\alpha \mathrm{BTX}$-positive and -negative regions, respectively. $e$, The same cell areas are indicated on the CTX image, showing an uneven distribution of the raft marker over the cell surface. $f$, Overlay of $d$ and $f$ indicates a high degree of colocalization of both markers. $g-i$, A ciliary neuron double-labeled with $\alpha$ BTX $(g)$ and phalloidin $(h)$ is shown; arrowheads in $g-i$ point to the same cell areas, which are positive for both markers $(i) . j-l$, Plots of the fluorescence intensity ratio between $\alpha \mathrm{BTX}$-positive and -negative areas of the cell surface are shown. $j$, Comparison of the fluorescence intensity ratio between $\alpha \mathrm{BTX}$ and NCAM ( $n=20$ cells) is shown. $k$, Comparison of the fluorescence intensity ratio between $\alpha \mathrm{BTX}$ and CTX $(n=19$ cells $)$ is shown. $l$, Comparison of $\alpha \mathrm{BTX}$ and phalloidin ( $n=20$ cells) is shown. Error bars indicate SE. Scale bar, $5 \mu \mathrm{m}$.

to monomeric actin and therefore sequesters G-actin. This results in a depolymerization of actin filaments and as a consequence causes the collapse of spines (Allison et al., 1998; Shoop et al., 2000). Two hours of LAT-A treatment did not induce a complete disappearance of F-actin filaments but caused a substantial reduction of the marker. Longer treatments were not performed because somatic spines of cultured ciliary neurons tend to collapse spontaneously after $4-6 \mathrm{hr}$ (Shoop et al., 2000).

\section{RESULTS}

\section{Membrane lipid rafts become progressively colocalized with the $\alpha 7 n A C h R$ during development of a ciliary neuron}

The chick CG is part of the autonomic system that brings the parasympathetic innervation to the internal muscles of the eye. Synapse formation on ciliary neurons can be divided into two major periods. Soon after the preganglionic fibers arrive at the 
ganglion (St 25), the presynaptic terminals form active synaptic contacts with ciliary neurons. This first phase extends up to St $33-34$, and by this time $100 \%$ of the neurons in the ganglion respond to preganglionic stimulation (Landmesser and Pilar, 1972). Although these bouton-like contacts are active, they are morphologically immature, and the resulting EPSPs are of small amplitude. After a brief period of multiple innervation, the bouton-like contacts are progressively replaced by a single synaptic contact. This second phase in formation of the calyciform synapse (from St 34 to 42), which includes the events studied here, involves the growth of the presynaptic calyx, the formation and maturation of synaptic complexes, and the development of so-

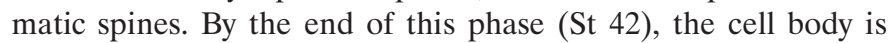
primarily covered by a single presynaptic calyx and is wrapped by Schwann cells (Landmesser and Pilar, 1972, 1976, 1978).

To determine whether changes in the distribution of organized lipid membrane components correlate with the formation of $\alpha 7$ nAChR-rich somatic spines in ciliary neurons, the developmental pattern of distribution of cholesterol-containing membrane microdomains and $\alpha 7 \mathrm{nAChR}$ was analyzed from the beginning (St 33) to the end (St 42) of the second phase of synapse formation. Intact $\mathrm{CGs}$ from St 33, 37, and 42 embryos were stained with RITC- $\alpha$ BTX and biotin-CTX followed by FITCstreptavidin and observed by confocal microscopy. Because the B subunit of CTX specifically binds to GM1, which is enriched in cholesterol-rich membrane microdomains, CTX is commonly used as a raft marker (Harder et al., 1998; Viola et al., 1999).

In accordance with previous reports (Corriveau and Berg, 1993; Blumenthal et al., 1999), it was found that $\alpha 7 \mathrm{nAChR}$ expression at St 33 is low (Fig. 1a). At this time, CTX labeling is distributed over the entire surface of ciliary neurons (Fig. 1d). As development progresses (St 37), the expression of $\alpha 7 \mathrm{nAChR}$ increases and becomes restricted to distinct regions of the cell surface (Fig. 1b). This process is accompanied by changes in the surface distribution of CTX, which becomes more concentrated, although not exclusively, into the same $\alpha \mathrm{BTX}$-positive regions (Fig. 1e,h, arrowheads). By the end of synapse formation (St 42), ciliary neurons have adopted a mature cellular architecture with clumps of somatic appendages distributed on discrete regions of the cell. These appendages that are $\sim 0.5 \mu \mathrm{m}$ wide by $2 \mu \mathrm{m}$ long resemble dendritic spines (De Stefano et al., 1993) and by St 40-42 have formed tightly folded aggregates or mats that contain high concentrations of $\alpha 7 \mathrm{nAChR}$ (Shoop et al., 1999). Accordingly, $\alpha$ BTX labeling reveals a few large, well defined patches over the cell surface (Fig. 1c, arrowheads), and CTX labeling is almost exclusively restricted to these same cellular structures (Fig. 1f,i, arrowheads). Thus, the similarity in the developmental pattern of $\alpha 7 \mathrm{nAChR}$ expression and lipid raft location suggests a possible association between this lipid membrane compartment and the neurotransmitter receptor.

\section{Cholesterol-rich lipid microdomains colocalize with $\alpha 7 n A C h R$ in somatic spines of dissociated cells}

At St 40-42, ciliary neurons can be isolated from CG by collagenase treatment and mechanical dissociation. This procedure preserves much of the surface composition and cellular architecture of the cells, including the $\alpha 7 \mathrm{nAChR}$ and somatic spines, the latter remaining intact for $\sim 6 \mathrm{hr}$ after plating (Shoop et al., 2000). To determine whether lipid rafts are differentially distributed on the surface of cultured ciliary neurons, freshly dissociated neurons were double-stained with RITC- $\alpha$ BTX and antibodies against NCAM or with RITC- $\alpha$ BTX and FITC-CTX. NCAM has been found previously to be evenly distributed on the surface of ciliary neurons (Brusés et al., 1995) and can be used as a marker of the overall distribution of surface membrane.

On cells labeled with $\alpha \mathrm{BTX}$ and NCAM, $\alpha \mathrm{BTX}$ staining is distributed over discrete areas of the cell surface (Fig. 2a, arrowheads). In contrast, NCAM staining is found over both $\alpha \mathrm{BTX}-$ positive and -negative areas (Fig. $2 b$, arrowheads, arrows, respectively). The difference in the distribution of both markers is illustrated by the overlay of both images (Fig. $2 c$ ). To quantify the differential distribution of $\alpha \mathrm{BTX}$ and NCAM over the cell surface, confocal midsection images of ciliary neurons were analyzed using NIH Image software (Fig. 2j). The average fluorescence intensity of a predetermined area was measured within the $\alpha \mathrm{BTX}$-positive region of the cell and divided by the average fluorescence intensity of an area of the same size positioned over an $\alpha$ BTX-negative region of the cell, which corresponds to the smooth surface of the membrane. The ratio for NCAM represents an even distribution of the marker on the cell surface. The slight apparent concentration of NCAM ( 3) within the $\alpha$ BTXpositive region is because of a higher membrane density per surface area within the aggregates of somatic spines. In contrast, $\alpha$ BTX has a high ratio $(\sim 25)$, indicating that the $\alpha 7 \mathrm{nAChR}$ is highly concentrated in discrete regions of the cell surface. A high ratio value for a particular marker indicates an accumulation of the marker within $\alpha$ BTX-positive patches (see Materials and Methods)

Similarly, CTX is localized to discrete areas of the cell surface that correspond to the areas labeled with $\alpha \mathrm{BTX}$ (Fig. 2d,e, arrowheads). The high degree of colocalization for both markers is shown in the overlay of both images (Fig. 2f). A comparison of the fluorescence intensity between $\alpha$ BTX-positive and -negative areas of the cell surface gave a high ratio for both CTX and $\alpha$ BTX (Fig. 2k). Because $\alpha 7 \mathrm{nAChRs}$ are concentrated in the mats of somatic spines, these results indicate that cholesterol-rich lipid microdomains are highly concentrated on the surface of somatic spines of ciliary neurons together with the $\alpha 7 \mathrm{nAChR}$.

To obtain ultrastructural evidence that somatic spines are enriched in lipid rafts, dissociated ciliary neurons were incubated with peroxidase-conjugated CTX followed by an anti-horseradish peroxidase (anti-HRP) antibody coupled to $6 \mathrm{~nm}$ gold particles. Samples were processed for transmission electron microscopy, and microphotographs were taken from areas of the cell with somatic spines (Fig. 3a) and from smooth surface membrane regions (Fig. 3b). To determine whether CTX is more abundant on the surface of somatic spines than on the smooth surface of the cell membrane, the number of gold particles over a distance of 20 $\mu \mathrm{m}$ of cell membrane was quantified for these two regions. The results shown in Figure $3 c$ indicate that the cell membrane on somatic spines is enriched in gold particles as compared with the smooth cell surface. Thus, both the confocal and EM analyses show that somatic spines are enriched in membrane lipid rafts.

\section{Cholesterol-rich lipid microdomains are necessary to maintain $\alpha 7 n A C h R$ clustering in somatic spines}

Lipid rafts are enriched in cholesterol, and the removal of cholesterol causes the dispersion of the components of lipid microdomains into the phospholipid bilayer of the cell membrane (Scheiffele et al., 1997; Harder et al., 1998; Keller and Simons, 1998). To determine whether rafts are required for the maintenance of $\alpha 7 \mathrm{nAChR}$ macroclusters within somatic spine aggregates, cholesterol was extracted from freshly dissociated St 40 ciliary neurons by treating the cells with $\mathrm{MBC}$, which selectively 

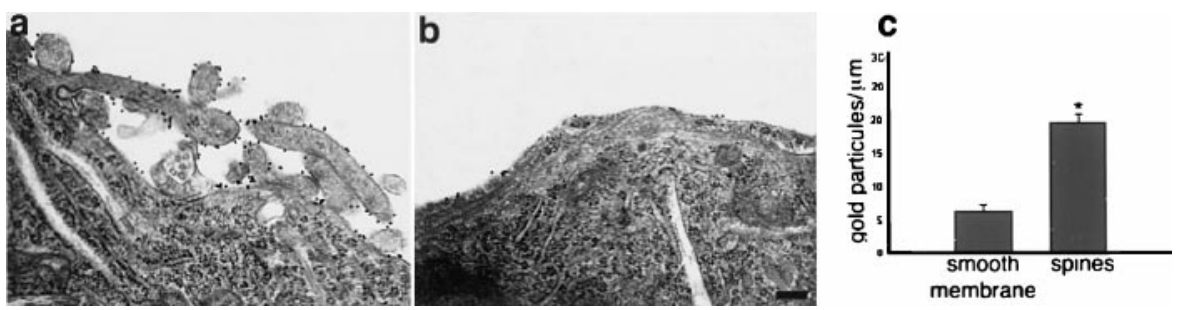

Figure 3. EM analysis of the distribution of lipid rafts on the surface of ciliary neurons. Dissociated ciliary neurons were incubated with HRPconjugated CTX followed by anti-HRP antibodies conjugated with $6 \mathrm{~nm}$ gold particles. $a$, $b$, Electron micrographs of somatic spines $(a)$ and smooth membrane $(b)$ show a higher density of gold particles over somatic spines. The size of each gold particle has been electronically enhanced to facilitate observation. $c$, Plot of the number of gold particles per micrometer detected over $20 \mu \mathrm{m}$ of smooth membrane and over somatic spines is shown $\left({ }^{*} p<\right.$ 0.0001 , Student's $t$ test). Error bars indicate SE. Scale bar, $0.2 \mu \mathrm{m}$.

extracts $60-70 \%$ of the cholesterol from the cell membrane (Keller and Simons, 1998). Cells were then double-labeled with RITC- $\alpha$ BTX and FITC-CTX and analyzed by confocal microscopy.

As shown in Figure $4 a-c$, lipid rafts and $\alpha 7 \mathrm{nAChR}$ are colocalized on untreated ciliary neurons (arrowheads). This colocalization is also illustrated in the fluorescence intensity plot of the cell circumference (Fig. 4d), which shows three distinct peaks of fluorescence corresponding to the areas of the cell indicated in the photograph (Fig. 4c, arrowheads). After cholesterol is removed, CTX disperses over most of the cell membrane, indicating the disruption of lipid microdomains (Fig. 4e). The surface distribution of $\alpha \mathrm{BTX}$ is similarly affected by the removal of cholesterol because the large clusters of $\alpha 7 \mathrm{nAChR}$ were fragmented into microclusters (Fig. $4 f$ ). Furthermore, whereas in the cholesterol-depleted cells the aggregates of both CTX and $\alpha$ BTX become smaller and more diffusely distributed, they also become spatially separated (Fig. $4 g$ ). This decrease in colocalization suggests that the forces responsible for $\alpha 7 \mathrm{nAChR}$ association with the lipid raft component GM1 within somatic spines are reduced as a consequence of the dispersion of the components of the cholesterol-rich lipid microdomains. The effect of removing cholesterol on the surface distribution of $\alpha \mathrm{BTX}$ and CTX is also illustrated in the fluorescence intensity plot shown in Figure $4 h$, in which several nonoverlapping peaks for each marker are detected (arrows). To quantify the effect of $\mathrm{MBC}$ on receptor clustering, two parameters were selected: the average number of $\alpha$ BTX clusters per cell section (Fig. 4i) and the average size of each cluster (Fig. 4j). As a result of MBC treatment, the average number of clusters per cell is significantly increased, whereas the average size of each cluster is significantly reduced.

\section{F-actin colocalizes with the $\alpha 7 \mathrm{nAChR}$, is depolymerized by cholesterol depletion, and affects both receptor clusters and lipid rafts}

Although the above studies implicate rafts in receptor clustering, they do not specify whether this relationship is direct or involves effects transmitted via other components or mechanisms that influence clustering. As indicated in the introductory remarks, the cytoskeleton and its linkage to surface receptors represent relevant factors. Somatic spines have a well organized cytoskeleton in the form of polymerized F-actin (Shoop et al., 2000). To determine the spatial relationship of F-actin to the $\alpha 7 \mathrm{nAChR}$, freshly dissociated ciliary neurons were double-labeled with $\alpha$ BTX and the F-actin marker phalloidin. As shown in Figure $2 g-i$, phalloidin is highly colocalized with $\alpha \mathrm{BTX}$ clusters, and the ratio of the average fluorescence intensity between $\alpha$ BTXpositive and -negative areas is very similar for these two markers

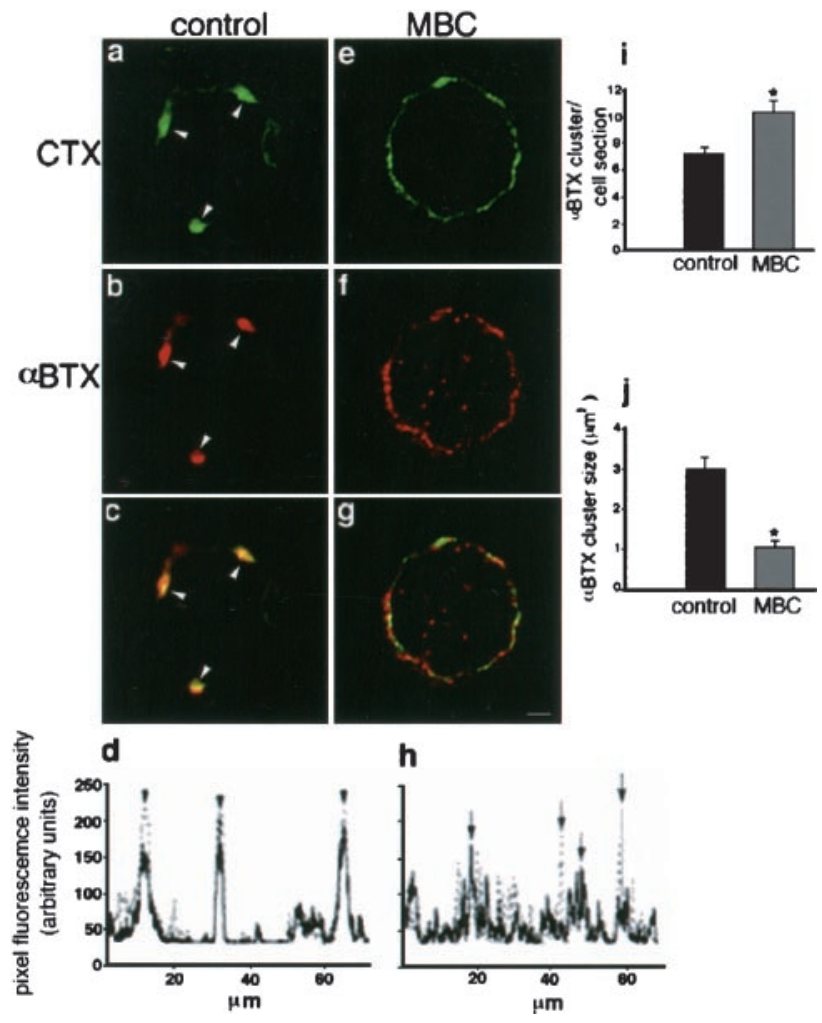

Figure 4. MBC treatment disrupts lipid rafts and causes the dispersion of the $\alpha 7 \mathrm{nAChR}$. Freshly dissociated St 40 ciliary neurons were left untreated $(a-c)$ or were depleted of cholesterol with $\mathrm{MBC}(e-g)$ and doublelabeled with RITC- $\alpha \operatorname{BTX}(b, f)$ and FITC-CTX $(a, e) . a-c$, Confocal sections of untreated cells are shown. a, Arrowheads point to three well defined clusters of lipid rafts as identified by CTX. $b$, Arrowheads point to the same cell region shown in $a$ indicating that this area is also $\alpha$ BTX positive and contains $\alpha 7 \mathrm{nAChR}$. $c$, Overlay of the images shown in $a$ and $b$ indicates in yellow the colocalization of both markers. $e-g$, Confocal sections of a cell after MBC treatment and labeling with $\alpha \mathrm{BTX}(f)$ and CTX $(e)$ are shown. $g$, Overlay of the images shown in $e$ and $f$ is given. $d$, Plot of the fluorescence intensity on the circumference of the cell shown in $c$ is given. Arrowheads point to the peaks of fluorescence corresponding to the cell regions indicated by arrowheads in $c$ (solid line, $\alpha \mathrm{BTX}$; dotted line, CTX). Note the high degree of overlap between both markers. $h$, Plot similar to that shown in $d$ from the MBC-treated cell is given. The large numbers of peaks detected on the cell treated with MBC correspond to the small clusters of $\alpha \mathrm{BTX}$ and CTX represented in $g$. Arrows indicate nonoverlapping peaks for each marker (solid line, $\alpha \mathrm{BTX}$; dotted line, CTX). $i$, Plot represents the average number of $\alpha \mathrm{BTX}$-positive clusters in control and MBC-treated cells $\left(n=20\right.$ cells; ${ }^{*} p<0.003$, Student's $t$ test). A cluster was defined as an area of 20 or more $\left(0.18 \mu \mathrm{m}^{2}\right)$ adjacent pixels positive for the marker. $j$, Plot represents the average size of each $\alpha$ BTX-positive cluster in control and MBC-treated cells $(n=20$ cells; ${ }^{*} p<0.001$, Student's $t$ test). Scale bar, $5 \mu \mathrm{m}$. 

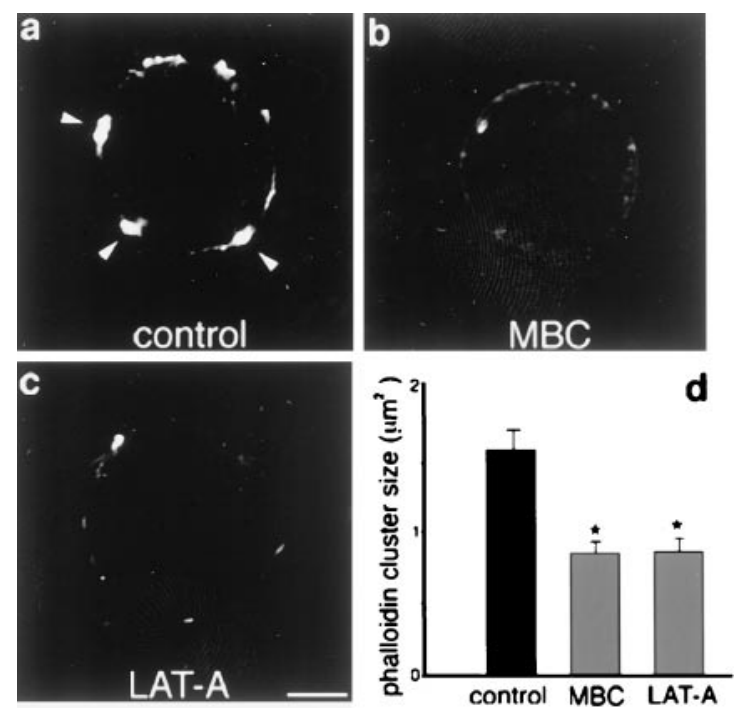

Figure 5. MBC or LAT-A treatment disrupts F-actin filaments. Freshly dissociated St 40 ciliary neurons were left untreated $(a)$, treated with MBC ( $8 \mathrm{~mm})$ for $1 \mathrm{hr}$ at $37^{\circ} \mathrm{C}(b)$, or treated with LAT-A $(20 \mu \mathrm{g} / \mathrm{ml})$ for $2 \mathrm{hr}$ at $37^{\circ} \mathrm{C}(c)$ and then labeled with RITC-phalloidin. a, Arrowheads point to well defined F-actin aggregates. $b$, MBC-treated cells show disruption of the F-actin cytoskeleton as a result of cholesterol removal. $c$, A similar effect is obtained with LAT-A treatment. $d$, Plot indicates the average size of phalloidin clusters found in control and treated cells. A cluster was defined as an area of 20 or more $\left(0.18 \mu \mathrm{m}^{2}\right)$ adjacent pixels positive for the marker. Error bars indicate SE. Each treatment was compared with control values independently $\left({ }^{*} p<0.001\right.$, Student's $t$ test). Scale bar, $5 \mu \mathrm{m}$.

(Fig. 2l). Because of this distribution, it was important to determine the functional relationship between F-actin and both receptor clustering and rafts.

Because the clustering of lipid rafts can induce F-actin polymerization (Harder and Simons, 1999), we tested whether cholesterol removal directly affects the F-actin cytoskeleton by treating cells with $\mathrm{MBC}$ and staining with phalloidin. As shown in Figure $5 a$, control cells show a discrete distribution of phalloidin in a few large patches on the cell surface. In contrast, after MBC treatment, phalloidin staining is faint and disperse, indicating the redistribution of the F-actin cytoskeleton over the cell surface (Fig. 5b). Accordingly, the average size of phalloidin-positive patches is substantially decreased in MBC-treated cells (Fig. 5d). This effect is similar to that found in cells treated with LAT-A, which selectively induces F-actin depolymerization (Fig. 5c). Thus, cholesterol-rich lipid microdomains appear to be required for the maintenance of both the clusters of $\alpha 7 \mathrm{AChR}$ and spineassociated F-actin filaments.

Because $\alpha 7 \mathrm{AChR}$ clusters could be anchored to the cytoskeleton, these experiments do not exclude the possibility that the dispersal of the receptor clusters observed after cholesterol depletion is secondary to the collapse of the spine produced by the depolymerization of the F-actin filaments. Moreover, treatment with LAT-A converts well organized $\alpha 7 \mathrm{nAChR}$ macroclusters (Fig. 6a, arrowheads) into small aggregates (Fig. 6d), so that the number of clusters significantly increases and the size of each cluster is significantly reduced (Fig. 6j, $k$, respectively). However, a similar effect is simultaneously observed for CTX aggregates (Fig. $6 e, j, k$ ). Some colocalization of the receptor with GM1 persists after the actin depolymerization but appears less complete than that in the control (Fig. 6, compare $c, f$ ). Therefore, because

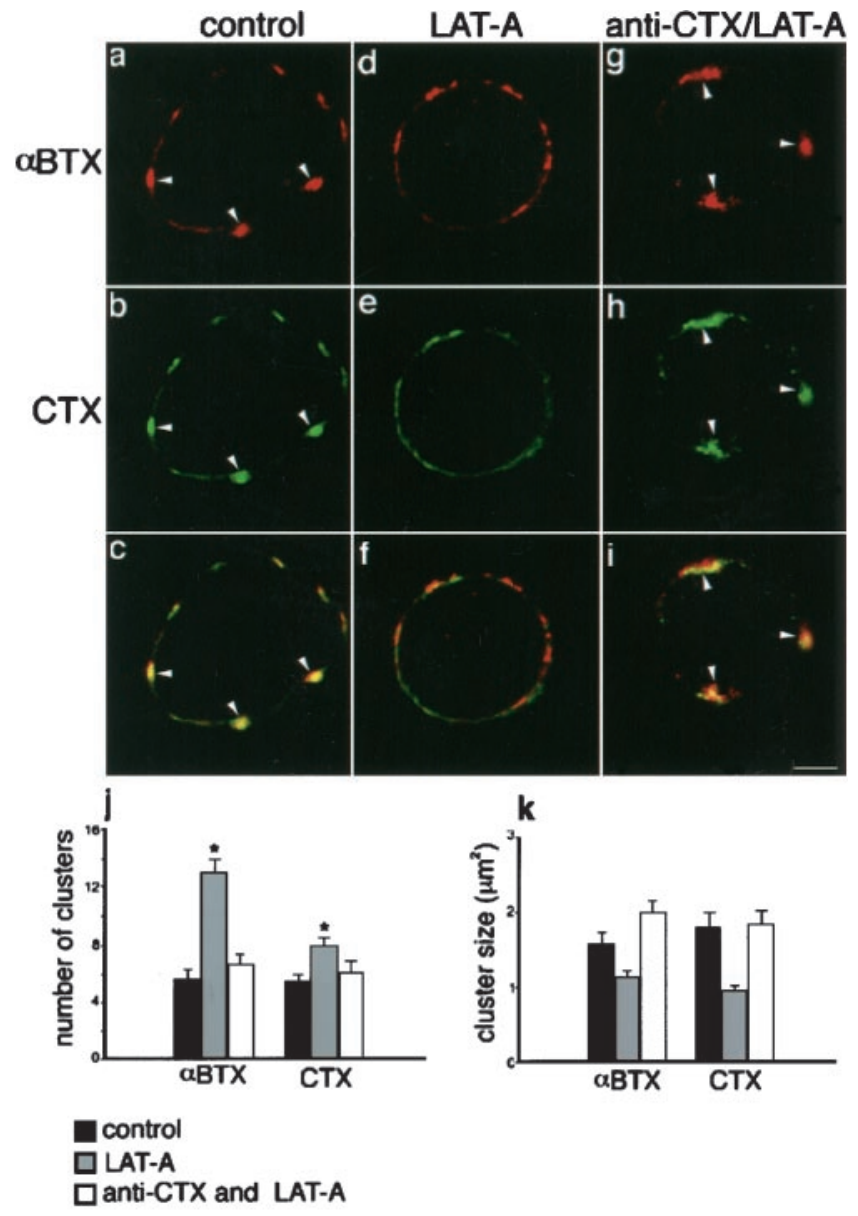

Figure 6. Patching of GM1 induces an F-actin-independent clustering of the $\alpha 7 \mathrm{nAChR}$. $a-c$, Confocal images of an untreated St 40 ciliary neuron double-labeled with RITC- $\alpha$ BTX $(a)$ and FITC-CTX $(b)$. $c$, Overlay of images in $a$ and $b$. Arrowheads indicate marker colocalization. $d-f$, St 40 ciliary neuron treated with LAT-A and labeled with RITC- $\alpha$ BTX $(d)$ and FITC-CTX (e). $f$, Overlay of images in $d$ and $e$ illustrating the disappearance of $\alpha 7 \mathrm{nAChR}$ and CTX clusters after treatment with the toxin. $g-i$, Confocal images of an St 40 ciliary neuron incubated with FITC-CTX and an antibody against CTX before LAT-A treatment and then labeled with RITC- $\alpha$ BTX. $g, \alpha$ BTX staining identifying clusters of $\alpha 7 \mathrm{nAChR}$ on the cell surface (arrowheads) that are colocalized with CTX $(h) . i$, Overlay of the images shown in $g$ and $h . j$, Number of $\alpha$ BTX and CTX clusters per cell section on control cells (black bars), LAT-A-treated cells (gray bars), and cells incubated with anti-CTX antibodies and then treated with LAT-A (white bars). $k$, Plot of the size of $\alpha$ BTX and CTX clusters under the same conditions shown in $j$. Treated cells were compared with control cells independently $\left({ }^{*} p<0.001\right.$, Student's $t$ test). Note that the number and size of clusters in cells incubated with anti-CTX antibodies and then treated with LAT-A are not different from those of control cells. Scale bar, $5 \mu \mathrm{m}$.

F-actin depolymerization affects both the integrity of lipid raft patches and $\alpha 7 \mathrm{nAChR}$ clusters, this type of study does not adequately determine whether there is a direct or indirect (via F-actin) relationship between rafts and receptor clustering.

\section{Antibody-stabilized lipid microdomains can maintain receptor clusters independently of the F-actin cytoskeleton}

To assess whether forces created by the interaction between lipid rafts and $\alpha 7 \mathrm{nAChR}$ can maintain receptor clustering independently of F-actin filaments, dissociated ciliary neurons were incubated with FITC-CTX followed by an antibody against CTX to 

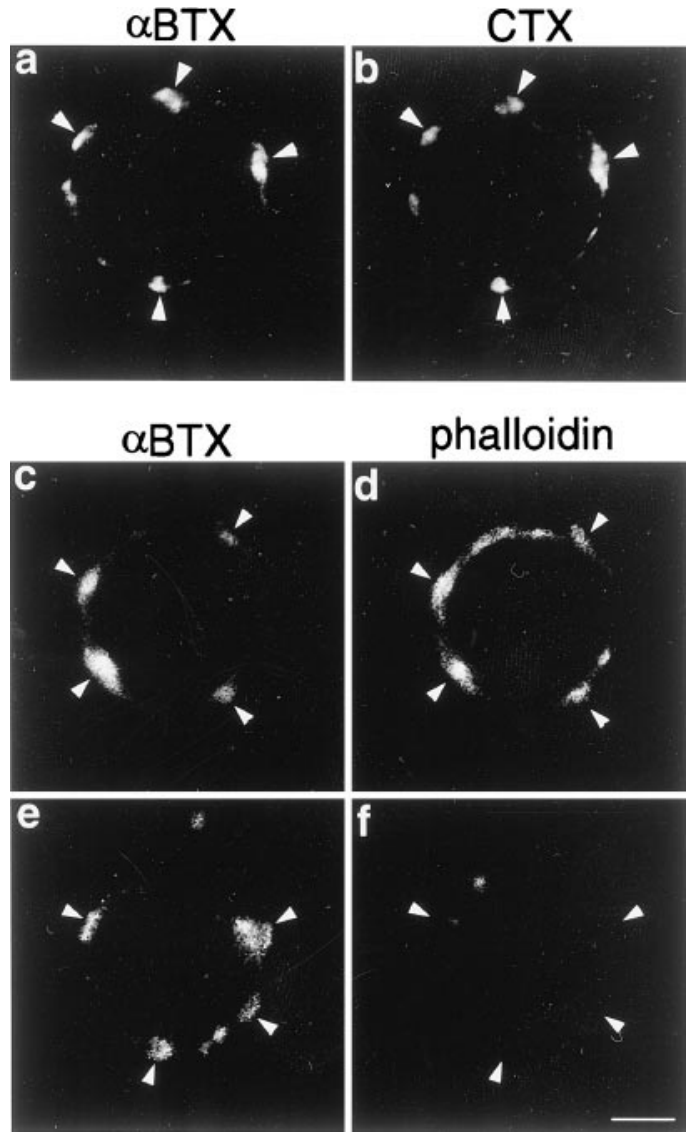

Figure 7. Anti-CTX antibodies do not affect the distribution of $\alpha 7 \mathrm{nAChR}$, lipid rafts, or F-actin cytoskeleton. Freshly dissociated ciliary neurons were incubated with RITC- $\alpha$ BTX and FITC-CTX $(a, b)$ or with Alexa488- $\alpha$ BTX and unconjugated CTX $(c-f)$ for $1 \mathrm{hr}$ on ice followed by a 30 min incubation with anti-CTX antibodies at $37^{\circ} \mathrm{C}$. Thereafter cells were either fixed $(a, b)$ or treated with LAT-A for $2 \mathrm{hr}$ at $37^{\circ} \mathrm{C}(e, f)$ or left untreated $(c, d)$ and stained with RITC-phalloidin after fixation $(c-f) . a$, $b$, Arrowheads point to well defined patches of $\alpha 7 \mathrm{nAChR}$ and lipid rafts on the same cell, indicating that treatment with antibodies against CTX does not change the distribution of either marker. $c, d$, Arrowheads point to patches of $\alpha 7 \mathrm{nAChR}$ and F-actin, respectively, also indicating that the antibody does not affect the organization of the cytoskeleton. e, Arrowheads point to patches of $\alpha 7 \mathrm{nAChR}$, which remained clustered by the anti-CTX antibody after treatment with LAT-A. f, Arrowheads point to the same cell regions shown in $e$, indicating the absence of F-actin cytoskeleton. Scale bar, $5 \mu \mathrm{m}$.

help stabilize the cholesterol-rich lipid microdomains. The addition of CTX and antibodies against CTX has been shown to cross-link GM1 and thereby increase the stability of lipid microdomains (Janes et al., 1999). Similarly, patches of CTX and $\alpha \mathrm{BTX}$ on ciliary neurons were found to be more resistant to $\mathrm{MBC}$ treatment in the presence of CTX and anti-CTX antibodies, because some patches of smaller size remained after the treatment (data not shown). CTX and anti-CTX antibodies by themselves did not change the appearance of either $\alpha 7 \mathrm{nAChR}$, lipid rafts, or F-actin filaments (Fig. $7 a-d$ ). When the cells were subsequently treated with LAT-A to depolymerize F-actin, CTX patches did in fact persist, although they tended to spread over a larger area of the cell surface after the collapse of the actindependent spines (Fig. 6h). The depolymerization of F-actin by LAT-A after lipid rafts were patched with CTX and anti-CTX antibodies was corroborated by staining with phalloidin (Fig. $7 e, f)$. Cells were then labeled with RITC- $\alpha \mathrm{BTX}$ and observed by

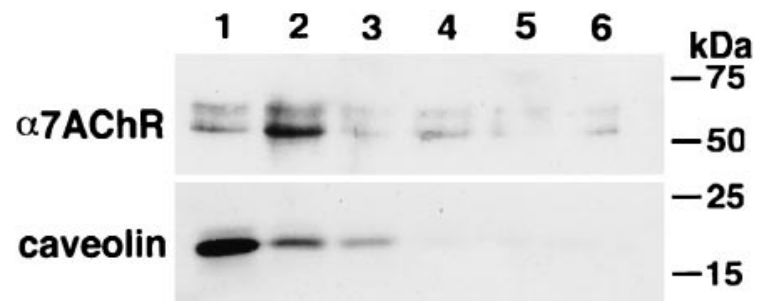

Figure $8 . \quad \alpha 7 \mathrm{nAChR}$ is associated with detergent-resistant membrane lipid microdomains. A membrane fraction from St 40-42 CGs was prepared by gradient centrifugation, incubated with Triton X-100 on ice for $30 \mathrm{~min}$, and subjected to discontinuous gradient centrifugation (35$30-0 \%$ Optiprep) at $285,000 \times g$ for $4 \mathrm{hr}$ at $4^{\circ} \mathrm{C}$. Six fractions were collected from the top (fraction 1) to the bottom (fraction 6 ). $\alpha 7 \mathrm{nAChR}$ was isolated from each sample with $\alpha$ BTX-conjugated Actigel, separated on $10 \%$ SDS-PAGE, and analyzed by Western blotting with a monoclonal antibody against the $\alpha 7 \mathrm{nAChR}$. An aliquot of each fraction was also analyzed by Western blotting with a polyclonal antibody against caveolin. The Western blots indicate that the bulk of $\alpha 7 \mathrm{nAChR}$ floats to the lower density fractions ( fraction 1, 2), indicating its association with detergentresistant membrane structures. The accumulation of the integral lipid raft protein caveolin in the first two fractions confirms the migration of the detergent-insoluble components of the membrane to the low-density portion of the gradient.

confocal microscopy to localize lipid rafts and the $\alpha 7 \mathrm{nAChR}$. As shown in Figure $6 h$, the large patches of CTX on the surface of the antibody/LAT-A-treated cells (arrowheads) are also positive for $\alpha$ BTX (Fig. 6g, $i$, arrowheads). The GM1 and $\alpha 7 \mathrm{nAChR}$ distribution in these stabilized patches was quantified by determining the average number of $\alpha \mathrm{BTX}$ and CTX clusters per cell section and the average size of each cluster (Fig. 6j, $k$, respectively, white bars). The number and size of both CTX and $\alpha \mathrm{BTX}$ clusters were undistinguishable from values obtained for the untreated cells. Together, these findings indicate that the stabilized lipid domains are able to retain their affinity for the $\alpha 7 \mathrm{nAChR}$ in the absence of F-actin, in accord with a direct interaction between the domain and the receptor.

\section{The $\alpha 7 \mathrm{nAChR}$ subunit is resistant to Triton $\mathrm{X}-100$ solubilization and partitions with the lipid raft fraction in density gradients}

One of the properties of proteins associated with cholesterol-rich membrane microdomains is their ability to remain insoluble in the presence of Triton $\mathrm{X}-100$ at $4^{\circ} \mathrm{C}$. Because this material has a high-lipid content, it floats during density gradient centrifugation (Brown and Rose, 1992). This method therefore can distinguish between proteins that are detergent insoluble because of their association with the cytoskeleton (they do not float) and those that are Triton X-100 resistant because of their association with lipid raft microdomains. To determine whether $\alpha 7 \mathrm{nAChR}$ is associated with membrane lipid rafts, St 40-42 CGs were homogenized, and the membrane fraction was isolated by gradient centrifugation. Thereafter, the membrane-containing fractions were extracted with Triton X-100 at $4^{\circ} \mathrm{C}$, separated by density gradient centrifugation, and analyzed by SDS-PAGE and Western blotting. As shown in Figure 8, a sizable fraction of the $\alpha 7 \mathrm{nAChR}$ is found in the low-density (top) fractions of the flotation gradient ( fractions 1, 2), indicating the association of the receptor subunit with detergent-resistant lipid microdomains. Traces of the receptor could also be detected in the higher density fractions (Fig. 8, fractions 3-6), indicating that not all receptor subunits are or remain associated with detergent-resistant membrane microdomains. The localization of the majority of caveolin, 
a known lipid raft component, in the first two fractions of the gradient confirms the position of the detergent-resistant lowdensity fraction. Because caveolin has not been reported to be expressed in substantial amounts in neurons, the caveolin detected by Western blots in CG homogenates likely is derived from Schwann and glial cells present in the CG and serves here only as a convenient marker.

\section{DISCUSSION}

This study provides direct evidence that the $\alpha 7 \mathrm{nAChR}$ is associated with cholesterol-rich membrane lipid microdomains and that maintenance of these receptors within somatic spine-rich regions of ciliary neurons is dependent on the presence of these microdomains within that structure. The results obtained also suggest that the F-actin at somatic spines plays a less direct role in receptor redistribution. The following discussion relates these findings to other work on lipid microdomains and then considers a series of issues concerning the molecular nature and function of receptorraft complexes in the somatic spine, as well as their relationship to the actin-based cytoskeleton.

There is ample evidence in other systems that association of transmembrane receptors and signaling molecules with cholesterol-rich microdomains provides a cellular mechanism for the concentration of receptor proteins to particular functional domains of the cell surface (Simons and Ikonen, 1997; Brown and London, 1998; Jacobson and Dietrich, 1999). For example, ephrinB1 is localized in cholesterol-rich rafts in which it associates with various signaling molecules including the glutamate receptor-interacting protein (GRIP). Stimulation of ephrinB1 with EphB2 receptor causes the formation of large raft patches that contain GRIP and induces serine/threonine kinase activity (Bruckner et al., 1999). Similarly, the activation of CD28 leads to the redistribution and clustering of kinase-rich lipid microdomains at the site of $\mathrm{T}$ cell receptor (TCR) engagement (Montixi et al., 1998; Grakoui et al., 1999; Harder and Simons, 1999). This redistribution of the TCR is mediated by the reorganization of membrane lipid microdomains (Janes et al., 1999), appears to involve the actin cytoskeleton (Viola et al., 1999), and depends on myosin motor proteins (Wulfing and Davis, 1998).

In the present case, the fact that some of the $\alpha 7 \mathrm{nAChR}$ did not float with caveolin-rich fractions suggests either that not all receptor molecules are incorporated into lipid rafts or that they partition between raft-associated and -unassociated states. A number of proteins are known to be functionally altered by a partial association with lipid rafts. For example, GRIP variably associates with lipid rafts via its interaction with ephrinB (Bruckner et al., 1999). A similar phenomenon can occur via binding to a linker protein that is variably associated with rafts. For example, the adhesion molecule CD44 associates with rafts via interaction with annexin II, which partitions into the rafts in a calciumdependent manner (Oliferenko et al., 1999).

In addition to an association with lipids, some raft-associated receptors also associate with the cytoskeleton via linker proteins. An example is annexin II, which associates with actin filaments as well as the cell membrane (Kube et al., 1992; Harder and Gerke, 1994). Thus, in the ciliary neuron, which accumulates rafts and an actin-based cytoskeleton in the same structure, an annexin II-like protein could participate in both the aggregation of the $\alpha 7$ nAChR-containing lipid rafts and their coupling to the actin cytoskeleton.

A direct role for F-actin in receptor clustering, which would be consistent with the observation that disruption of the actin fila- ments with LAT-A causes dispersion of $\alpha 7 \mathrm{nAChR}$ clusters, remains less clear. The difficulty in demonstrating such a role stems from the fact that the structure of the spine itself requires an intact actin cytoskeleton (Shoop et al., 2000). Moreover, cell surface patching of the raft component GM1 by CTX is known to cause accumulation of filamentous actin (Harder and Simons, 1999), suggesting that the clustering of lipid rafts leads to the recruitment of F-actin to help form the somatic spines. Similarly, the integrity of actin cytoskeleton in neurons has been shown to influence the association of both $\alpha 7 \mathrm{nACh}$ and NMDA receptors with spines (Allison et al., 1998; Shoop et al., 2000); yet the localization of these receptors or associated molecules to spines is independent of actin filaments and resistant to detergent extraction (Allison et al., 2000; Shoop et al., 2000). These observations would again suggest that the role of the cytoskeleton is indirect and probably occurs via its ability to form or maintain the spine. Nevertheless, the view that actin fiber recruitment lies "downstream" of raft aggregation is probably overly simplistic, because the cytoskeleton may well contribute to additional structuring of this lipid domain and is known to be a factor in molding that cell surface region into a mature somatic spine.

Finally, it is not yet clear what signals and processes underlie the clustering of lipid rafts on ciliary neurons during synaptogenesis and whether this process serves to induce as well as maintain the distribution of the $\alpha 7 \mathrm{nAChR}$. In the case of the formation of the neuromuscular junction, the clustering of the nAChR is induced by the release of agrin from the presynaptic axonal terminal that binds to MUSK, the muscle-specific tyrosine kinase, and activates a tyrosine phosphorylation cascade that ends in the clustering of rapsyn and the nAChR (Gautam et al., 1995, 1996; DeChiara et al., 1996; Glass et al., 1996a,b; Apel et al., 1997; Sanes and Lichtman, 1999). Although the molecular details of these events have not been completely elucidated, it is clear from these studies that a nerve-derived signal activates the machinery for receptor clustering. If we speculate that rafts can be clustered on the surface of ciliary neurons via such an extracellular signal, the progressive colocalization of lipid rafts and $\alpha 7 \mathrm{nAChR}$ during synapse formation in the CG may not be merely coincidental events. Instead the aggregation of lipid microdomains would be a key early event both in the molecular organization of the synapse as well as in the formation of somatic spines.

In summary, it is becoming evident that $\alpha 7 \mathrm{nAChR}$ and other neurotransmitter receptors are associated directly or via linker proteins with cholesterol-rich membrane microdomains. In addition, lipid rafts are required to maintain receptor clustering and may induce the polymerization of F-actin bundles that constitute the spine cytoskeleton. It will now be important to identify the nature of the physical interaction between receptors and lipid rafts and to determine whether linker molecules participate in this interaction.

\section{REFERENCES}

Allison DW, Gelfand VI, Spector I, Craig AM (1998) Role of actin in anchoring postsynaptic receptors in cultured hippocampal neurons: differential attachment of NMDA versus AMPA receptors. J Neurosci 18:2423-2436.

Allison DW, Chervin AS, Gelfand VI, Craig AM (2000) Postsynaptic scaffolds of excitatory and inhibitory synapses in hippocampal neurons: maintenance of core components independent of actin filaments and microtubules. J Neurosci 20:4545-4554.

Apel ED, Glass DJ, Moscoso LM, Yancopoulos GD, Sanes JR (1997) Rapsyn is required for MuSK signaling and recruits synaptic components to a MuSK-containing scaffold. Neuron 18:623-635.

Barnard EA (1992) Receptor classes and the transmitter-gated ion channels. Trends Biochem Sci 17:368-374. 
Blumenthal EM, Shoop RD, Berg DK (1999) Developmental changes in the nicotinic responses of ciliary ganglion neurons. J Neurophysiol $81: 111-120$.

Brown DA, London E (1998) Functions of lipid rafts in biological membranes. Annu Rev Cell Dev Biol 14:111-136.

Brown DA, Rose JK (1992) Sorting of GPI-anchored proteins to glycolipid-enriched membrane subdomains during transport to the apical cell surface. Cell 68:533-544.

Bruckner K, Pablo Labrador J, Scheiffele P, Herb A, Seeburg PH, Klein R (1999) EphrinB ligands recruit GRIP family PDZ adaptor proteins into raft membrane microdomains. Neuron 22:511-524.

Brusés JL, Oka S, Rutishauser U (1995) NCAM-associated polysialic acid on ciliary ganglion neurons is regulated by polysialytransferase levels and interaction with muscle. J Neurosci 15:8310-8319.

Burns A, Benson D, Howard J, Margiotta J (1997) Chick ciliary ganglion neurons contain transcripts coding for acetylcholine receptorassociated protein at synapses (rapsyn). J Neurosci 17:5016-5026.

Conroy WG, Berg DK (1999) Rapsyn variants in ciliary ganglia and their possible effects on clustering of nicotinic receptors. J Neurochem 73:1399-1408.

Corriveau RA, Berg DK (1993) Coexpression of multiple acetylcholine receptor genes in neurons: quantification of transcripts during development. J Neurosci 13:2662-2671.

Craven SE, Bredt DS (1998) PDZ proteins organize synaptic signaling pathways. Cell 93:495-498.

Craven SE, El-Husseini AE, Bredt DS (1999) Synaptic targeting of the postsynaptic density protein PSD-95 mediated by lipid and protein motifs. Neuron 22:497-509.

DeChiara TM, Bowen DC, Valenzuela DM, Simmons MV, Poueymirou WT, Thomas S, Kinetz E, Compton DL, Rojas E, Park JS, Smith C, DiStefano PS, Glass DJ, Burden SJ, Yancopoulos GD (1996) The receptor tyrosine kinase MuSK is required for neuromuscular junction formation in vivo. Cell 85:501-512.

De Stefano ME, Ciofi Luzzatto A, Mugnaini E (1993) Neuronal ultrastructure and somatostatin immunolocalization in the ciliary ganglion of chicken and quail. J Neurocytol 22:868-892.

Feng G, Steinbach JH, Sanes JR (1998a) Rapsyn clusters neuronal acetylcholine receptors but is inessential for formation of an interneuronal cholinergic synapse. J Neurosci 18:4166-4176.

Feng G, Tintrup H, Kirsch J, Nichol MC, Kuhse J, Betz H, Sanes JR (1998b) Dual requirement for gephyrin in glycine receptor clustering and molybdoenzyme activity [see comments]. Science 282:1321-1324.

Froehner SC (1991) The submembrane machinery for nicotinic acetylcholine receptor clustering. J Cell Biol 114:1-7.

Gautam M, Noakes PG, Mudd J, Nichol M, Chu GC, Sanes JR, Merlie JP (1995) Failure of postsynaptic specialization to develop at neuromuscular junctions of rapsyn-deficient mice [see comments]. Nature 377:232-236.

Gautam M, Noakes PG, Moscoso L, Rupp F, Scheller RH, Merlie JP, Sanes JR (1996) Defective neuromuscular synaptogenesis in agrindeficient mutant mice. Cell 85:525-535.

Glass DJ, Bowen DC, Stitt TN, Radziejewski C, Bruno J, Ryan TE, Gies DR, Shah S, Mattsson K, Burden SJ, DiStefano PS, Valenzuela DM, DeChiara TM, Yancopoulos GD (1996a) Agrin acts via a MuSK receptor complex. Cell 85:513-523.

Glass DJ, DeChiara TM, Stitt TN, DiStefano PS, Valenzuela DM, Yancopoulos GD (1996b) The receptor tyrosine kinase MuSK is required for neuromuscular junction formation and is a functional receptor for agrin. Cold Spring Harb Symp Quant Biol 61:435-444.

Grakoui A, Bromley SK, Sumen C, Davis MM, Shaw AS, Allen PM, Dustin ML (1999) The immunological synapse: a molecular machine controlling T cell activation [see comments]. Science 285:221-227.

Hamburger V, Hamilton HL (1951) A series of normal stages in the development of the chick embryo. J Morphol 88:49-93.

Harder T, Gerke V (1994) The annexin II2p11(2) complex is the major protein component of the Triton X-100-insoluble low-density fraction prepared from MDCK cells in the presence of $\mathrm{Ca}^{2+}$. Biochim Biophys Acta 1223:375-382.

Harder T, Simons K (1999) Clusters of glycolipid and glycosylphosphatidylinositol-anchored proteins in lymphoid cells: accumulation of actin regulated by local tyrosine phosphorylation. Eur J Immunol 29:556-562.

Harder T, Scheiffele P, Verkade P, Simons K (1998) Lipid domain structure of the plasma membrane revealed by patching of membrane components. J Cell Biol 141:929-942.

Jacobson K, Dietrich C (1999) Looking at lipid rafts? Trends Cell Biol 9:87-91.

Janes PW, Ley SC, Magee AI (1999) Aggregation of lipid rafts accompanies signaling via the $\mathrm{T}$ cell antigen receptor. J Cell Biol 147:447-461.

Keller P, Simons K (1998) Cholesterol is required for surface transport of influenza virus hemagglutinin. J Cell Biol 140:1357-1367.

Klein S, Bikfalvi A, Birkenmeier TM, Giancotti FG, Rifkin DB (1996) Integrin regulation by endogenous expression of $18-\mathrm{kDa}$ fibroblast growth factor-2. J Biol Chem 271:22583-22590.
Kornau HC, Schenker LT, Kennedy MB, Seeburg PH (1995) Domain interaction between NMDA receptor subunits and the postsynaptic density protein PSD-95. Science 269:1737-1740.

Kornau HC, Seeburg PH, Kennedy MB (1997) Interaction of ion channels and receptors with PDZ domain proteins. Curr Opin Neurobiol $7: 368-373$.

Kube E, Becker T, Weber K, Gerke V (1992) Protein-protein interaction studied by site-directed mutagenesis. Characterization of the annexin II-binding site on p11, a member of the S100 protein family. J Biol Chem 267:14175-14182.

Landmesser L, Pilar G (1972) The onset and development of transmission in the chick ciliary ganglion. J Physiol (Lond) 222:691-713.

Landmesser L, Pilar G (1976) Fate of ganglionic synapses and ganglion cell axons during normal and induced cell death. J Cell Biol $68: 357-374$

Landmesser L, Pilar G (1978) Interactions between neurons and their targets during in vivo synaptogenesis. Fed Proc 37:2016-2022.

Ledesma MD, Simons K, Dotti CG (1998) Neuronal polarity: essential role of protein-lipid complexes in axonal sorting. Proc Natl Acad Sci USA 95:3966-3971.

Liu Q, Berg DK (1999) Actin filaments and the opposing actions of CaM kinase II and calcineurin in regulating $\alpha 7$-containing nicotinic receptors on chick ciliary ganglion neurons. J Neurosci 19:10280-10288.

Meyer G, Kirsch J, Betz H, Langosch D (1995) Identification of a gephyrin binding motif on the glycine receptor beta subunit. Neuron 15:563-572.

Montixi C, Langlet C, Bernard AM, Thimonier J, Dubois C, Wurbel MA, Chauvin JP, Pierres M, He HT (1998) Engagement of T cell receptor triggers its recruitment to low-density detergent-insoluble membrane domains. EMBO J 17:5334-5348.

Oliferenko S, Paiha K, Harder T, Gerke V, Schwarzler C, Schwarz H, Beug H, Gunthert U, Huber LA (1999) Analysis of CD44-containing lipid rafts: recruitment of annexin II and stabilization by the actin cytoskeleton. J Cell Biol 146:843-854.

Phillips WD, Kopta C, Blount P, Gardner PD, Steinbach JH, Merlie JP (1991) ACh receptor-rich membrane domains organized in fibroblasts by recombinant 43-kilodalton protein. Science 251:568-570.

Prior P, Schmitt B, Grenningloh G, Pribilla I, Multhaup G, Beyreuther K, Maulet Y, Werner P, Langosch D, Kirsch J (1992) Primary structure and alternative splice variants of gephyrin, a putative glycine receptortubulin linker protein. Neuron 8:1161-1170.

Ramarao MK, Cohen JB (1998) Mechanism of nicotinic acetylcholine receptor cluster formation by rapsyn. Proc Natl Acad Sci USA 95:4007-4012.

Sanes JR, Lichtman JW (1999) Development of the vertebrate neuromuscular junction. Annu Rev Neurosci 22:389-442.

Scheiffele P, Roth MG, Simons K (1997) Interaction of influenza virus haemagglutinin with sphingolipid-cholesterol membrane domains via its transmembrane domain. EMBO J 16:5501-5508.

Schon A, Freire E (1989) Thermodynamics of intersubunit interactions in cholera toxin upon binding to the oligosaccharide portion of its cell surface receptor, ganglioside GM1. Biochemistry 28:5019-5024.

Shoop RD, Martone ME, Yamada N, Ellisman MH, Berg DK (1999) Neuronal acetylcholine receptors with $\alpha 7$ subunits are concentrated on somatic spines for synaptic signaling in embryonic chick ciliary ganglia. J Neurosci 19:692-704.

Shoop RD, Yamada N, Berg DK (2000) Cytoskeletal links of neuronal acetylcholine receptors containing $\alpha 7$ subunits. J Neurosci 20:4021-4029.

Simons K, Ikonen E (1997) Functional rafts in cell membranes. Nature 387:569-572.

Spector I, Shochet NR, Kashman Y, Groweiss A (1983) Latrunculins: novel marine toxins that disrupt microfilament organization in cultured cells. Science 219:493-495.

Stauffer TP, Meyer T (1997) Compartmentalized IgE receptor-mediated signal transduction in living cells. J Cell Biol 139:1447-1454.

Vandekerckhove J, Deboben A, Nassal M, Wieland T (1985) The phalloidin binding site of F-actin. EMBO J 4:2815-2818.

Viola A, Schroeder S, Sakakibara Y, Lanzavecchia A (1999) T lymphocyte costimulation mediated by reorganization of membrane microdomains [see comments]. Science 283:680-682.

Wang H, Bedford FK, Brandon NJ, Moss SJ, Olsen RW (1999) GABA(A)-receptor-associated protein links GABA(A) receptors and the cytoskeleton. Nature 397:69-72.

Watanabe M, Frelinger AL, Rutishauser U (1986) Topology of NCAM structural and functional determinants. I. Classification of monoclonal antibody epitopes. J Cell Biol 103:1721-1727.

Wulfing C, Davis MM (1998) A receptor/cytoskeletal movement triggered by costimulation during T cell activation. Science 282:2266-2269.

Xia J, Zhang X, Staudinger J, Huganir RL (1999) Clustering of AMPA receptors by the synaptic PDZ domain-containing protein PICK1. Neuron 22:179-187. 